\title{
PRODUCTION AND COST OF COLD PATCH ROAD MATS WITH BITUMEN EXTRACTED FROM NIGERIAN TAR SAND
}

\author{
F. F. Adebayo ${ }^{1}$ and Y. A. Jimoh ${ }^{2}$ \\ 1, 2 DEPARTMENT OF CIVIL ENGINEERING, UNIVERSITY OF ILORIN, ILORIN, NIGERIA \\ E-mail addresses: ${ }^{1}$ ffadebayo.fa@gmail.com, ${ }^{2}$ yaj@unilorin.edu.ng
}

\begin{abstract}
This paper reports the production of bituminous road mats with bitumen sourced from the Nigerian Tar sand, recycled waste rubber and paper, and rock mineral aggregates for cold patching of flexible pavement. The bitumen extracted was evaluated for yield, physical and mechanical properties in accordance with ASTM and AASHTO procedures. The bitumen was mixed with rubber chips to produce rubberized bitumen for production of road mats. The unit cost of production per square metre of the road mat was developed and compared with that of the imported Broom Road Product (BRP). The bitumen extracted from the Nigerian tar sand is suitable as straight run bitumen and production of bituminous cold patch road mats at relatively cheaper cost than the BRP. An immediate action plan for exploitation of the untapped resources of bitumen should be instituted by government and private entrepreneurs for production of road mats for cold patching of flexible roads.
\end{abstract}

Key Words: Tar sand, Road mats, Straight run bitumen, Recycled waste from tyres and kraft paper.

\section{INTRODUCTION}

Road surface patches, either partial or full depth, are common methods of treating an area of localized distress. Typically hot-mix asphalt (HMA) patches are full depth [1] and generally used for road repairs as a routine maintenance practice. Cold mix asphalt, on the other hand, is used for road patching only with placement advantage without the stringent quality control of the HMA and lower working temperature. In the full depth repairs, the HMA must be delivered to the job site within a fixed period of time and condition, while the mix had to be continually heated till the pothole or localized distress being repaired is appropriately accomplished. This is cumbersome and most times ineffective as the constraints by either the weather and or haulage distance to the repair points from the asphalt production yards becomes safety challenges and too expensive for small street repairs. Many prepared pothole locations are left uncompleted until HMA quality required meets the minimum quantity of purchase order dictated by an external supplier. The potholes would eventually become challenges to the suspension system of the transporting vehicles, and may cause accidents as drivers dodge the potholes. In fact, the cold patch technology has been adopted in most developed countries as a viable alternative to the prolonged hot mix asphalt method of road repairs in terms of weather and environmental friendliness and timeliness in immediate application.

One of the forms of cold asphalt pavement maintenance repairs is road mat products patented as BRP mat in South Africa and whose innovative costeffectiveness for modern day pavement maintenance, management and stabilization has been accomplished in South Africa [2] and most recently being patronized in Nigeria [3]. BRP mat patch is a factory fabricated road repair product manufactured on Kraft paper onto which a rubberized bitumen binder hold the precoated aggregates of various sizes. BRP road patch is supplied in sheets, at dimensions of $1.0 \mathrm{~m}$ by $0.75 \mathrm{~m}$ with a mass of between 4 and $20 \mathrm{~kg}$ depending on the aggregates size, and have been reported to have been successfully used to repair bituminous roads in South Africa [2]. BRP road maintenance product is characterized by quickness, simplicity and overall economic benefits in installation because it normally creates minimum disruption to traffic. It easily conforms to technical and technological specification, eliminates waste, and reduces skilled labour intensity

* Corresponding Author, Tel: +234-803-398-6545 
because its production is under factory control conditions. One other major reason that rekindled the interest of Cold Patching which has resulted in its worldwide use today is its use in the wet season and the ease of application without requiring so much labour and equipment [4].

The only local source of bitumen at present in Nigeria is at the Kaduna refinery which is also based on external sources, because it is a by-product of imported heavy crude from Venezuela, whereas Nigeria can boast of a huge deposit of tar sand in Ilubirin, Agbabu and Loda, Ondo State, which is still largely untapped. The Nigerian tar sand deposit is up to about 14.86 billion barrels in quantity, characterized to yield bitumen of $25 \%$ and designated as good to medium grade for reasonable economic investment since the yield is more than $5-10 \%[5,6$ and 7]. The desirable socio-economic multiplier effects for a developing economy such as Nigeria with the respective high bitumen yield and desirable quality for pavement works needs no emphasis.

With the motor industry developing and spreading at a higher pace in all parts of the world, high amount of scrap tires are produced every year, which makes the disposal of tyres a serious environmental problem [8]. Waste tyres constitute a serious environmental problem that many countries have to face as they accumulate rapidly and they are neither easily disposed of nor degradable. An estimated 5 million scrap tyres from trucks, cars and motorcycle existed in Nigeria in 1983. With an annual generation rate of $15 \%$, each year about $700-850$ thousand scrap tyres are added to the waste stream. About 15 million scrap tyres are now estimated to exist in Nigeria [9]. Many approaches have been considered in recent years for treating and improving the conventional asphalts, such as the introduction of the additives in order to improve their properties. The use of crumb rubber from waste tyres in asphalt has been an alternative to minimize their ecological impact and, simultaneously, to improve the mechanical properties of the asphalt mixtures [10] because rubber fibre as a naturally occurring polymer when added to bitumen increases its elasticity and softening point but decreases its brittleness. The addition also offsets any tendency for the richer material to be prone to wheel tracking [11] because the addition of the crumb rubber into the virgin asphalt induces a significant increase in the binder viscosity. As viscous property of asphalt rubber is critical to mixture compaction temperature and binder workability during storage and pumping process, the viscosity of asphalt rubber has been the central focus in previous research work [12] and [13]. Rubber is generally added to bitumen when it is being laid over areas that are known to be liable to reflective cracking, whether it be from joints in concrete roads, failure of lean concrete road or underlying movement in the road pavement [11].

Kraft paper is paper produced by Kraft process from wool pulp. It is strong and relatively coarse. Kraft paper is usually a brown colour but can be bleached to produce white paper. It is used for paper grocery bags, multi wall sacks, envelopes and other packaging. Its main function in the road mat production is to act as the carpet on which the bituminous mixes would be laid for desirable curing to be accomplished. The aggregate used for chip seals defines how well the seal will perform. The best aggregates have high durability, abrasion resistance; contain little, if any dust and nearly one-sized as much as possible [14]. The surface texture should be rough and the aggregate should be resistant to polishing under traffic.

The fact that a road can be opened to traffic immediately after application of the cold patching to reduce traffic congestion and the concomitant economic losses on the road during the maintenance work involving patching of pothole on busy or peak period traffic, coupled with the potential to generate employment for the dwellers in the vicinity of the deposit and the nation at large, makes the study imperative. The aim of the research therefore is to produce bituminous road mats using locally sourced materials as cost effective alternative to prolong time consuming and health hazardous hot mix asphalt and the imported broom road mats currently in use for cold mix pothole repairs in Nigeria. The objectives include the extraction of bitumen from Nigerian tar sand and characterisation for standard bituminous mixes, production of rubberized bitumen binder, fabrication of bituminous road mats with the rubberized binder, determination of unit cost of production of the road mats and establishment of the economic advantage of locally fabricated road mats over the imported BRP for pot holes repairs in Nigeria.

\section{Materials and Methods}

The materials needed for fabrication of the cold patch road mat consist of bitumen, aggregates, crump rubber and kraft paper. 


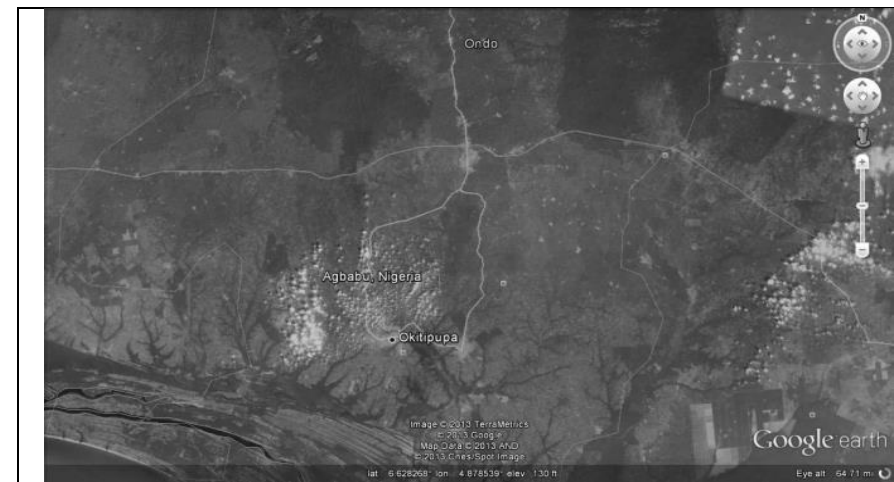

Figure 1: Satellite imagery showing location of Agbabu in

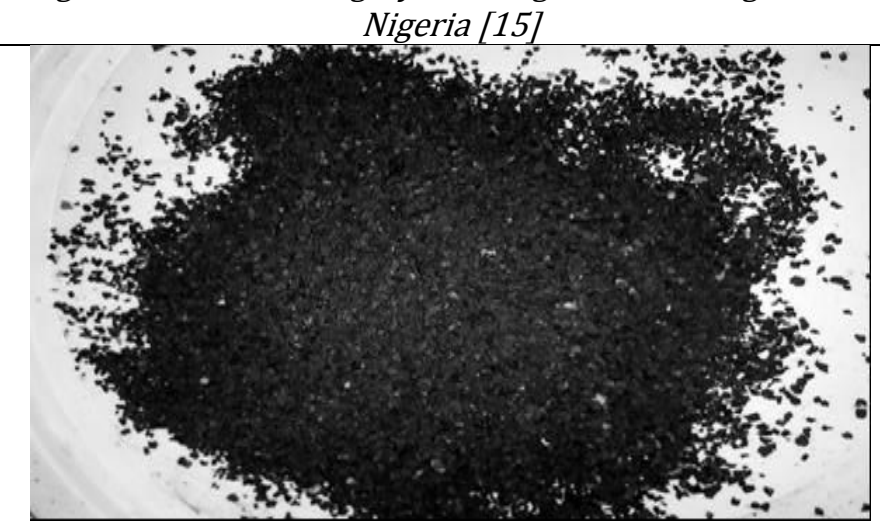

Figure 3: Heap of rubber chips produced from used tyres



Figure 4: Sample of three sizes and a mixture of the three of aggregates used for the research

\subsection{Bitumen}

The bitumen used for this research was extracted from the tar sand of Ilubirin, Loda and Agbabu in Ondo State. Figure 1 presents the satellite imagery of the location of the major tar sand deposits in Ondo State. In all the visited deposit locations, tar sand was found either at the surface of the ground or shallow depths and on water surfaces. Manual sampling of tar sand was employed just on the clearing of the grasses and shrubs on the surface. In Ilubirin the bitumen tar sand was extracted on the surface of flowing stream with utmost ease, just as if one were fetching water from the stream. The samples taken were most likely outcroppings and seeps that have migrated to the

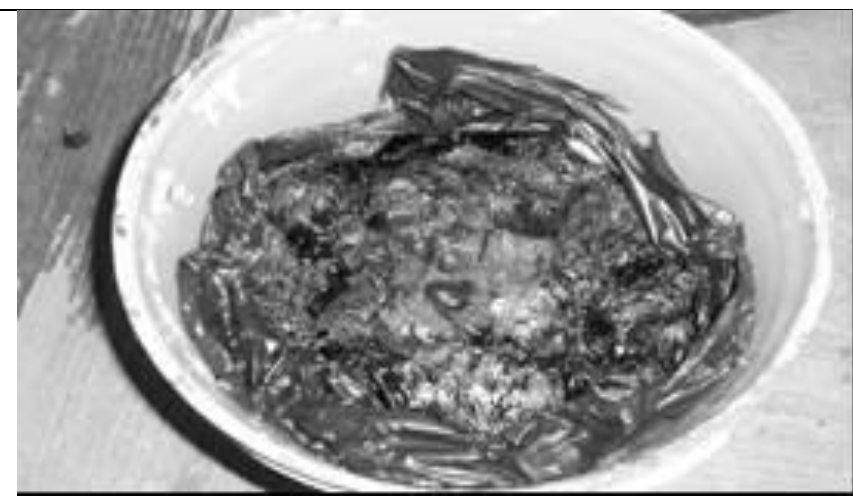

(a)

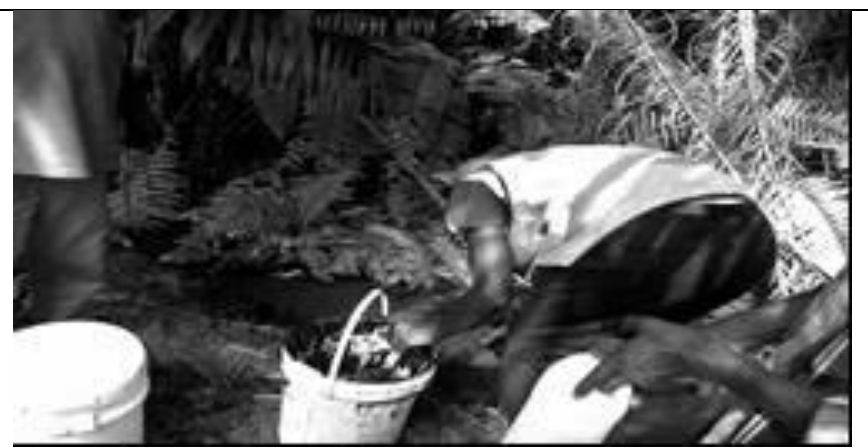

(b)

Figure 2: (a) Sample of tar sand used for the research (b) Scooping of tar sand from surface of a stream at Ilubirin

surface over time due to lack of commercial mining of the bitumen. Figure $2 \mathrm{a}$ and $2 \mathrm{~b}$ show the pictorial view of the tar sand sample collected from one of the locations and scooping of tar sand from the surface of a stream respectively.

\subsection{Granulated chips and the Aggregates}

Granulated chips of rubber were produced from used tyres for the purpose of this work. Disposed used tyres were collected and cut into pieces. These were then taken to a local rubber/plastic grinding factory located at Abule-Egba, Lagos state, where it was grinded. Figure 3 and Figure 4 shows the heap of the rubber chips and samples of aggregate sizes used respectively. For the purpose of this study, $15 \%, 20 \%$, $25 \%, 30 \%$ and $35 \%$ of granulated rubber by weight of bitumen was used. The mineral aggregates used for the research was sourced from Bellison Nig. Ltd Quarry, Ilorin, Kwara State. Sieve analysis was carried out to arrive at gradation of the aggregates with sizes ranging from 0.075 to $12.5 \mathrm{~mm}$. Three different sizes of aggregate granite chippings $(4.75,9.5,12.5 \mathrm{~mm})$ and mixture of the three sizes in ratio 1:1:1 were employed in the production of the bituminous road mats. 
The Kraft Paper: Kraft paper from used powder milk cartoon was used for this research. Kraft paper is paper produced by Kraft process from wool pulp. It is used for paper grocery bags, multi wall sacks, envelopes and other packaging and becomes waste hazard thereafter until designed for other alternative use. The Kraft papers used for this project were bought from powdered milk seller at the rate of N50.00 per bag which was used to produce two samples of the mat. Figure 5 shows a sample of used cartoon milk bag. The characteristics of this Kraft paper in terms of density, thickness and colour were found to be $1.1 \mathrm{~g} / \mathrm{cc}, 0.25 \mathrm{~mm}$ and brown/white respectively.

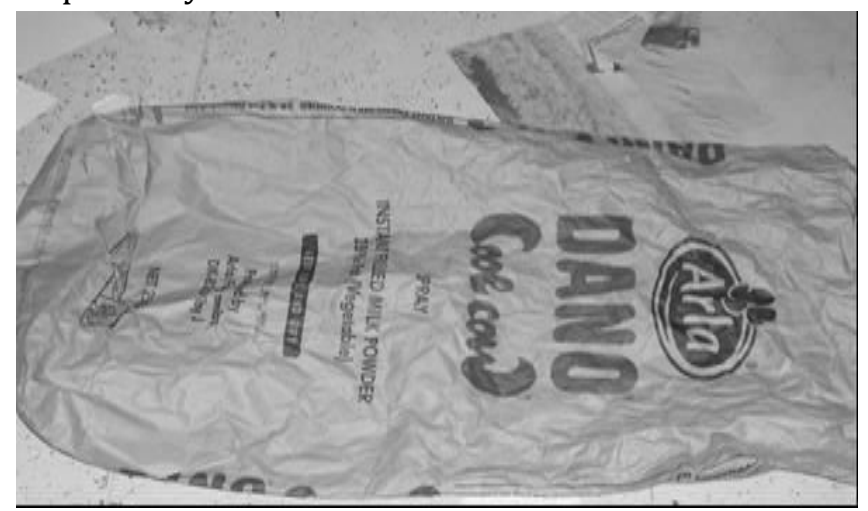

Figure 5: A sample powdered milk bag

\subsection{Extraction of bitumen from tar sand}

A make shift extraction process of bitumen from locally available tar sand was used. Some 25 litres of water was heated to a temperature of $30-35^{\circ} \mathrm{C}$ inside a pre-weighed 90 litres drum. About $10 \mathrm{~kg}$ of mined tar sand from Ondo state Tar sand deposit was transferred into the water at the temperature and allowed to increase to about $90^{\circ} \mathrm{C}$ accompanied with continuous stirring. Between $85^{\circ} \mathrm{C}$ and $90^{\circ} \mathrm{C}$ temperature, the bitumen was easily expelled to the surface of the boiling water when the heat source was removed, and the floating bitumen was scooped off from the top of the water inside a pre- weighed container. Accompanying water then flowed to the surface of the bitumen storage after the solidification of the bitumen. The water was then dispensed off and the sample re-weighed. Fig.6 shows schematic diagram of extraction of bitumen from tar sand.

\subsection{Evaluation of the Locally Sourced Materials}

The bitumen extracted from the Ilubirin, Loda and Agbabu Tar Sand deposits were characterised with the corresponding international standards for the physical, strength and other properties.
Heating of about 25 litres of water to around $30^{\circ} \mathrm{C}-35^{\circ} \mathrm{C}$

Add about $10 \mathrm{~kg}$ of tar sand + heat $\left(90^{\circ} \mathrm{C}\right)$

Scooping the floating bitumen at about $85^{\circ} \mathrm{C}-90^{\circ} \mathrm{C}$ in a container

After solidification, the accompany water will be dispose off

Figure 6: Schematic diagram of extraction of bitumen from tar sand

The tests are Density (ASTM D70-03), Specific Gravity (ASTM D70-03), Kinematic viscosity (ASTM D217007), Penetration (ASTM D5-06e1), Flash Point (ASTM 92-05a) and Spot (AASHTO T102). The artificial coarse aggregates were sourced from Bellison Nig. Ltd Quarry, Ilorin. The tests performed on the Bellison chippings with respective standard British procedures (BSI) are: Aggregate Crushing Value, (ACV) (BS 812 110:1990), Los - Angeles Aggregate Abrasion Index (BS 812-113:1990), Elongation Index (BS 812 105.2:1990), Flakiness Index (BS 812-105.1:1989), the Specific Gravity (BS 812 Part 2:1995) and Water Absorption (BS 812 Part 2:1995). Fig.7 presents the grading curves of the three sizes of the mineral aggregates used for the road mats and mixture of the three sizes in ratio $1: 1: 1$

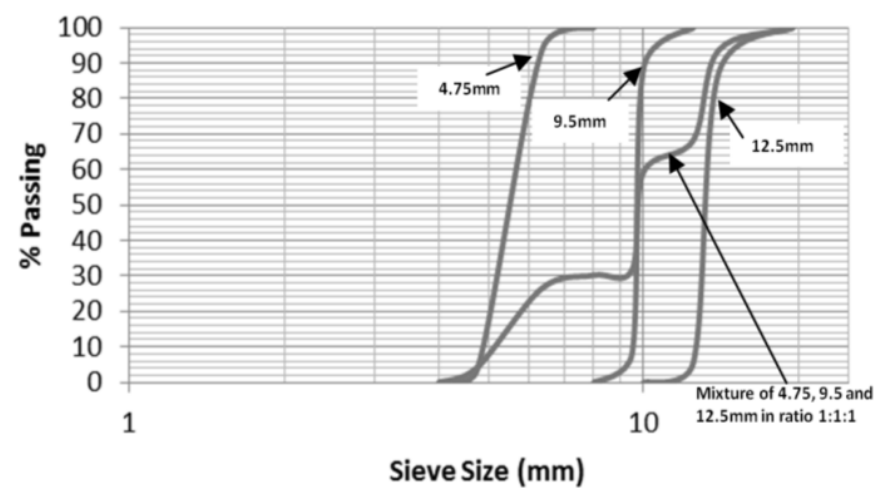

Figure 7: Grading Curves of the three sizes of Mineral aggregates used

\subsection{Production Process for Cold Patch Road Mat from the local Materials}

The extracted bitumen was heated to about $80^{\circ} \mathrm{C}$ to which was added 15, 20, 2530 and $35 \%$ of granulated rubber, by weight. The heating was continuous until the rubber chips have substantially blended with the 
bitumen which occurred at about $160^{\circ} \mathrm{C}$ to produce the rubberized bitumen. The Kraft paper $\left(0.27 \mathrm{~m}^{2}\right)$ of dimension $450 \times 600 \mathrm{~mm}$ was placed on the wooden form work. Aggregates of nominal sizes (4.75, 9.5, $12.5 \mathrm{~mm}$ or a mixture of the three sizes in equal proportion by weight) were evenly spread on the kraft paper; ensuring their complete compactness and tightness. About 0.81 litre of rubberized bitumen was then sprayed on the aggregates tightly placed on the Kraft paper $\left(0.27 \mathrm{~m}^{2}\right)$ to produce the road mats which translate to 3litre $/ \mathrm{m}^{2}$. The produced Road Mats were air cured for 7 days to gain initial strength. The flow chart of the production of the road mat is as depicted in Fig. 8, while the samples of the final product of locally produced cold patch road mat is as depicted in Fig. 9.

\subsection{Production cost development}

In order to develop a realistic unit cost of production for the bituminous road mat, a market survey of the prices of the various components was undertaken in Ilorin during the months of December 2013 and January 2014. The outcome was used to develop the prevailing material unit cost ensuring that the respective transportation costs were reflected. The quantities of the materials were also computed based on the mat size of 450 by $600 \mathrm{~mm}$ and rubberized bitumen spray rate of 3 litre $/ \mathrm{m}^{2}$. The production rate was $\mathrm{N} 1,671.90 / \mathrm{m} 2$ and at hiring rate remuneration for semi-skilled labour in the semi urban region of Nigeria. The various rates/cost are translated to a unit rate of square meter of mat for a comparison of the unit cost of the locally produced cold patch road mat with the cost of the imported BRP mat. The latter was purchased at the rate of N5, 000.00 per square metre. The cost and quantity data base employed for development of the unit price is presented in the Appendix.

\section{DISCUSSIONS OF RESULTS}

\subsection{Properties of the materials.}

Tables 1-3 present the outcome of the various laboratory tests performed respectively on the extracted bitumen, the aggregates and the cost of fabrication of the bituminous road mat. The standard values (specifications) for bituminous pavement works [26] were also included in order to clearly present a compliance status for the various mix components.



Figure 8: Production stages of locally produced cold patch road mat



Figure 9: Final product of locally produced cold patch road mat

Table1-Characterisation of the Nigerian tar sand bitumen

\begin{tabular}{clccc}
\hline S/NO & Property & $\begin{array}{c}\text { Average value of } 3 \\
\text { trials }\end{array}$ & $\begin{array}{c}\text { Specification (AASHTO, } \\
\text { 2005) }\end{array}$ & Remarks \\
\hline 1 & $\begin{array}{l}\text { Bitumen yield from tar } \\
\text { sand, (\%) }\end{array}$ & $47.32-88.23$ & - & - \\
2 & Density, g/cc & 1.026 & $1.01-1.05$ & $\begin{array}{c}\text { Satisfactory as it falls within } \\
\text { specification } \\
\text { Satisfactory as it falls within } \\
\text { specification }\end{array}$ \\
3 & Fire \& flash point, ${ }^{\circ}$ C & 227 & $220-230$ & - \\
4 & Impurities (Fine) & $9.64-18.34$ & - & - \\
5 & Impurities (Sand), \% & $2.13-42.63$ & - & Satisfactory as it falls within \\
specification
\end{tabular}




\begin{tabular}{llcc}
7 & Penetration, mm & 85 & $80 / 100$ \\
8 & Specific gravity & 1.035 & $1.00-1.05$ \\
9 & Spot test & Uncracked & Uncracked \\
\hline
\end{tabular}

Satisfactory as it falls within specification

Satisfactory as it falls within specification Satisfactory

Table.2-Characteristics of aggregates

\begin{tabular}{llcll}
\hline S/NO & Property & $\begin{array}{l}\text { Average Value of 3 } \\
\text { trials }\end{array}$ & $\begin{array}{l}\text { Specification (FGN, } \\
\text { 1997) }\end{array}$ & Remarks \\
\hline 1 & $\begin{array}{l}\text { Aggregate crushing value } \\
(\%)\end{array}$ & 23.59 & Not more than 30 & $\begin{array}{l}\text { Satisfactory as it falls } \\
\text { within specification }\end{array}$ \\
2 & $\begin{array}{l}\text { Loss Angeles Aggregate } \\
\text { Abrasion Index (\%) }\end{array}$ & 16.43 & Not more than 20 & $\begin{array}{l}\text { Satisfactory as it falls } \\
\text { within specification }\end{array}$ \\
3 & Elongation index (\%) & 30.92 & Not more than 35 & $\begin{array}{l}\text { Satisfactory as it falsl } \\
\text { within specification } \\
\text { Satisfactory as it falls } \\
\text { within specification }\end{array}$ \\
4 & Flakiness index (\%) & 23.17 & Not more than 35 & - \\
5 & Specific gravity & 2.55 & Not more than 0.5 & $\begin{array}{l}\text { Satisfactory as it falls } \\
\text { within specification }\end{array}$ \\
\hline
\end{tabular}

Table 3: Approximate unit cost of production of road mat

\begin{tabular}{rccccc}
\hline S/No & Description & Quantity & Rate $(\mathrm{N})$ & Unit & Amount (N) \\
\hline 1 & Aggregate & 0.018 & $3,700.00$ & Ton & 66.60 \\
2 & Kraft paper & 1 & 25.00 & $\mathrm{~m}^{2}$ & 25.00 \\
3 & Bitumen & 3 & 175.00 & Litre & 525.00 \\
4 & Rubber & 0.77 & 666.67 & $\mathrm{Kg}$ & 513.34 \\
5 & Labour & 1 & 240.00 & $\mathrm{~m}^{2}$ & 240.00 \\
6 & Fuel & & & 150.00 \\
7 & \multicolumn{5}{c}{ Sub-Total } \\
8 & Allow 10\% for other incidental cost & $1,519.91$ \\
\multicolumn{5}{c}{ Total } \\
\hline
\end{tabular}

Table 4. Parameters for Comparative Analysis of the fabricated Road Mat and the BRP

\begin{tabular}{cccc}
\hline S/NO & Property & $\begin{array}{c}\text { Locally Produced Cold Patch Road } \\
\text { Mat }\end{array}$ & $\begin{array}{c}\text { BRP (Imported Cold } \\
\text { Patch Road Mat) }\end{array}$ \\
\hline 1 & Size of Aggregate $(\mathrm{mm})$ & $\begin{array}{c}4.75,9.5,12.5 \text { and mixture of the } \\
\text { three sizes }\end{array}$ & 4.75 and 9.5 \\
2 & Mat Size $(\mathrm{mm})$ & 450 X 600 & 750 X 1000 \\
3 & Weight $\left(\mathrm{kg} / \mathrm{m}^{2}\right)$ & Between 17 and 27 & Between 13.5 and 19.5 \\
4 & Area $\left(\mathrm{m}^{2}\right)$ & 0.27 & 0.75 \\
5 & Kraft Paper Thickness (mm) & 0.25 & 0.225 \\
6 & Kraft Paper Colour & Brown/white & Brown \\
\hline
\end{tabular}

The extracted bitumen from the Nigerian tar sand from three communities reflects the desired properties for road surfacing binder. The AASHTO specifications for road materials [2005] were substantially satisfied for bituminous mixes in general and road mat fabrication. This result agrees substantially with the reported properties for the Nigerian tar sand bitumen prior to modification with rubber chips. 
The results of the various tests carried out on the aggregates indicated that the qualities of the aggregates are within the required standards for road works in Nigeria [FGN1997]. Similar observations were made of the other properties, that is, the flakiness index $(23.17 \%$, less than $35 \%)$ and water absorption ( $0.27 \%$ less than $0.5 \%)$, Los Angels' abrasion index (16.34\% less than 20\%) specification. These aggregates meet the minimum requirement for bituminous surfacing in Nigeria, a typical sub-tropical region.

Also the test results on the kraft paper compared favourably with those of the imported samples of the kraft paper. The colour, density and thickness respectively of brown/white, $1.1 \mathrm{~g} / \mathrm{cc}$ and $0.25 \mathrm{~mm}$ were in complete agreement with the specifications for road mat. This implies the likelihood of the satisfaction of the functions of the kraft paper in the performance of locally produced cold patch road mat. It is also an alternative use for the packaging paper instead of being discarded and thrown away.

\subsection{Comparative Analysis of Physical Properties of BRP and Locally Produced Cold Patch Road Mat}

Despite the fact that the locally produced cold patch road mat and the imported BRP are produced with the same sizes of aggregate of $4.75 \mathrm{~mm}$ and $9.5 \mathrm{~mm}$, the resultant mass/ unit area varies. Sieve analysis in general has been used for decades to monitor material quality based on particle size and it assumes that all particles will be round or nearly round and will pass through the square openings. However elongated and flat particles in a sieve analysis will not yield reliable results, as the particle sizes reported will be based on assumption of similar size in three dimensions.

\subsection{Production costs of cold patch mat from Nigerian tar sand.}

A comparison of price of the locally produced cold patch mat to the imported BRP cold patch from South Africa indicates a very substantial advantage. The Nigerian tar sand cold patch mat was produced at a rate of less than $\mathrm{N} 1,671.90$ for a sheet of $1.00 \mathrm{~m}^{2}$ as against that of $\mathrm{N} 5,000$ for the same area with the imported BRP cold patch. This shows a 300\% difference in favour of the locally produced cold patch mat. It will be a welcome development for cost reduction in the pavement maintenance with cold patch once the post installation performance of the Nigerian cold patch road mats is satisfactory or reasonably comparable with that reported for the imported mats.

The development of the extraction of bitumen from the tar sand will add value to the entire economy of the rural area of deposit in particular and Nigeria in general. The foreign reserve depletion in the process of paying for either the imported BRP or the bitumen alone will drastically reduce because at present Nigeria spend about Seventy-Two Billion Naira (N72 billion) annually on importation of bitumen for road construction [28]. The present price of bitumen is N175/litre which means that Nigeria import about 450,000 tonne of bitumen per annual. The work further reveals that, the road mat fabricated substantially from locally sourced materials and or yet untapped natural resources has the significant elimination of sustained boxing out of potholes in readiness for cold patching, applicable in normal/cold adverse weather conditions, no-expensive tools and road opening to traffic immediately after repair or patching. It is equally environmentally friendly because of the usage of the used tyre, provides a highly flexible and totally water proof seal. The use of crumb rubber from waste tyres has been an alternative to minimize their ecological impact and, simultaneously, to improve the mechanical properties of the binder (bitumen) mixtures.

\section{CONCLUSIONS AND RECOMMENDATIONS}

\subsection{Conclusions}

Based on the results of the research carried out on the production of bituminous road mats from locally sourced materials, costing and in comparison with an imported Broom Road Products already commonly in use by Federal Road Maintenance Agency [FERMA] for cold asphalt patching and road maintenance, the following conclusions were deduced:

i) The bitumen extracted from the Nigerian tar sand deposits, are appropriate in terms of yield for commercial investment and compliance with pavement surfacing works in Nigeria.

ii) The rubberised bitumen and the physical and strength properties of the mineral aggregates are in consonance with the Nigerian national and the international standards of BS, ASTM and other conditions for bituminous surfacing.

(iii) For economic consideration, the locally produced bituminous cold patch mats produced at a cost of $\$ 1,671.90$ per square meter has about 300\% cost advantage over the South African imported BRP mats and may even imply 
a much higher potential of generating more employment, if manufactured in large and commercial quantity.

\subsection{Recommendations}

The followings are recommended to further support the local fabrication of the cold patch mat:

a) A consideration of the Locally Produced cold patch mats for roads in preference to the imported ones should be given a high premium based on the over $300 \%$ cost advantage, and on the confirmation of suitability of Ilubirin, Loda and Agbabu (in Ondo state) tar sand for the fabrication of cold patch mat. The exploitation of the bitumen from this tar sand deposit should be more seriously pursued by both the government and or the private investors because it has a high catalytic influence on employment generation.

b) The possibility of mass production of this local cold patch should be further studied from the mechanical/industrial point of view.

\section{REFERENCES}

[1] Washington Asphalt Pavement Association (WAPA), (2010). Available for download at www.asphaltwa.com/2010/09/17/maintenance/ accessed on January 21, 2013.

[2] BRP (2008). BRP Road Maintenance Manual, A.J. BROOM ROAD PRODUCTS (PTY) LIMITED. Available for download at http://www.brp.co.za/pages/catalogue/page01.ht $\underline{m}$ accessed on January 11, 2013.

[3] Federal Road Maintenance Agency (FERMA), 2007, A Three day Training of FERMA Engineers on Converting Road into Mats (FERMA headquarter, Abuja.

[4] ARRA, "Basic Asphalt Recycling Manual", Asphalt Recycling and Reclaiming Association (ARRA), Federal Highway Administration, USA, 2001.

[5] Sheikh, G.M, 2003, "Bitumen Exploitation and Development in Nigeria", A paper presented to the Nigerian Society of Engineers LAGBELU by Goni M. Sheikh, Secretary Nigerian Bitumen Project QTR 52, Alagbaka G.R.A Akure, Ondo state, Nigeria.

[6] FMSMD, "Technical Overview in Nigeria's Bitumen Belt and Development Potential", Report of Federal Ministry of Solid Minerals Development, Abuja, Nigeria, March, 2006, PP. 1-14.

[7] Oshinowo, T., Ademodi, B., Adediran, A.S., "Bituminous Tar Sands of Nigeria": Analysis of Oils Part 1. Journal of the Nigerian Society of Chemical Engineers (1982) , 1(1): 44-48.
[8] Kiser J. V., "Asphalt Rubber Overcoming the Obstacles Scrap", Scrap Magazine Jan./Feb. 2003, pp. $46-52$

[9] Oyedepo O. J. and Oluwajana S. D., "Evaluation of Properties of Bitumen Modified with waste Tyre", Nigerian Journal of Technology (NIJOTECH), Vol. 33, No. 1, 2014, pp. 119-124.

[10] Liseane P.T.L. Fontes, Glicerio Triches, Jorge .C. Pais and Paulo A.A. Pereira, 2010, "Evaluating Permanent Deformation in Asphalt Rubber Mixtures", Construction and Building Materials, 2010; 24:1193-1200.

[11] Summer, C.J., (2006). Modified Bitumen and Bituminous Materials. Article available for download at http/www.highwaysmaintenance.com/rubtext.htm accessed on March 22, 2013.

[12] Lee S. J., Akisetty C. K. and Amirkhanian S. N., "Recycling of laboratory-prepared long-term aged binders containing crumb rubber modifier", Construction and Building Material, 22(9) (2008), pp. 1906-1913

[13] Akisetty C. K., Lee S. J. and Amirkhanian S. N., "Effects of compaction temperature on volumetric properties of rubberized mixes containing warmmix additives", Journal of Materials in Civil Engineering, 21 (8) (2009), pp. 409-415

[14] Hutter Werner, (2005), "Crack Reduction Strategies on Asphalt Pavement" Research Report, 2001-2008, Report No 2003-2005 pdf Files Downloaded at www.dot.state.co.us/publications/ResearchReports htm assessed on March 23, 2013.

[15] Google Map available at https://maps.google.com assessed on March 23, 2013.

[16] ASTM D70-03 (2003), "Standard test method for specific gravity and density of semi-solid bituminous materials (Pycnometer method)", ASTM international/10-Jan-2003.

[17] ASTM D2170-07 (2001), "Standard test method for kinematic viscosity of asphalts (Bitumen)", ASTM international, 2001.

[18] ASTM D5-06e1 (1996), "Standard test method for penetration of bituminous materials".

[19] ASTM D92-05a (2005), "Standard test method for flash and fire points by Cleveland open cup tester", ASTM international/01-Jul-2005/10pages.

[20] AASHTO T102 (1983) "Standard method of test for spot test of asphaltic materials", American Association of state Highway and Transportation Officials. Publication date: Jan 1, 1983.

[21] BS 812 -110:1990 "Methods determination of aggregates crushing value", British standard institution, 29-June -1990. 
[22] BS 812 -113:1990 "Methods determination of aggregates abrasion value", British standard institution, 29-June-1990.

[23] BS 812 -105.2:1990 "Methods determination of particle shape", Elongation index of coarse aggregate, British standard institution, June 1990.

[24] BS 812 -105.1:1989 "Methods determination of particle shape", Flakiness index of coarse aggregate, British standard institution, Jan., 1990.

[25] BS 812 Part 2:1995 "Methods determination of density", British standard institution, Aug., 1995.

[26] AASHTO (American Association of State Highways and Transportation Officials) Standards for Road Materials (2005).

[27] FGN (1997), The Nigerian General Specifications for Roads and Bridges volume II, 1997, Federal Republic of Nigeria, Federal Ministry of Works.

[28] Egunyomi D.A and Adekunle .0., "Mobilization Strategies for Effective Community relations between Bitumen Companies and Shareholders in Nigeria", Journal of Soc. Sci., 23(2):105-110, 2010.

\section{APPENDIX: UNIT COST AND QUANTITY USED FOR DEVELOPING THE ROAD MAT PRICE}

Material Price market survey, Ilorin, 2014)

1. Cost of aggregate per ton $=\mathrm{N} 2,700.00 \mathrm{~K}$

Cost of transportation per ton/KM $=\mathrm{N} 50.00$

From quarry to Tanke is about $20 \mathrm{~km}$ therefore cost of transportation per ton $=\mathrm{N} 1000.00$

Cost per $\mathrm{kg}=\mathrm{N} 3,700.00 \div 1000=\mathrm{N} 3.70 \mathrm{~K}$

2. Cost of kraft paper per $\mathrm{m}^{2}=\mathrm{N} 25.00 \mathrm{~K}$

3. Cost of bitumen $(60 / 70)$ per drum (200 litres) $=$ $\mathrm{N} 35,000.00 \mathrm{~K}$
Cost of bitumen per litre $=\mathrm{N} 35,000.00 \div 200=$ $\mathrm{N} 175.00 \mathrm{~K}$

4. Cost of granulated rubber per bag $(15 \mathrm{~kg})=\mathrm{N} 10$, $000.00 \mathrm{~K}$

Cost of granulated rubber per $\mathrm{kg}=\mathrm{N} 10,000.00 \div 15$ $=\mathrm{N} 666.67$

\section{Computation of quantities:}

Size of the mat is $600 \mathrm{~mm}$ by $450 \mathrm{~mm}$ or $0.27 \mathrm{~m}^{2}$

Weight of the aggregate used (average) $=(4.6+4.9) / 2$ $=4.75 \mathrm{~kg}$

Converting it into $\mathrm{kg} / \mathrm{m}^{2}$

Therefore: $-4.75 \div 0.27$ equal to $17.59 \sim 18 \mathrm{~kg} / \mathrm{m}^{2}$

For bitumen

0.81 litre of bitumen was used for $0.6 \mathrm{~m}$ by $0.45 \mathrm{~m}$ of mat size

Therefore: -0.81 litre $\div 0.27 \mathrm{~m}^{2}$ equal to 3litre $/ \mathrm{m}^{2}$

For rubber chips (taken $25 \%$ by weight of bitumen into consideration)

Rubber chips are $25 \%$ by weight of bitumen.

Density of bitumen extracted from Tar Sand is $1.026 \mathrm{~g} / \mathrm{cc}$ $1.026 \mathrm{~g} / \mathrm{cc}$ is equivalent to $1.026 \mathrm{~kg} / \mathrm{L}$

$1.026 \mathrm{~kg} / \mathrm{L} \times(25 \div 100) \times 3$ Litres $=0.77 \mathrm{~kg}$ of rubber chips

For labour

Labour per hour $=\mathrm{N} 150.00(\mathrm{~N} 1,200$ for eight hours for semi-skilled labour)

Two labour for eight (8) hours $=\mathrm{N} 2,400.00$

Assuming that two labour made 10 square meter of mat in eight hours

Therefore one square meter $=\mathrm{N} 2,400 \div 10=\mathrm{N} 240.00$ 